\title{
Second Nature and the Sonic Sublime
}

\author{
Miranda Stanyon, King's College London
}

\section{I}

In 1759, the year he published the second, enlarged edition of Edmund Burke's Philosophical Enquiry into the Origin of our Ideas of the Sublime and the Beautiful, Robert Dodsley toured Wales, taking in the estate of Valentine Morris at Piercefield:

The Place is certainly of the great and sublime Kind; most of the near Views are seen below you from the Top of high Precipices, consisting of steep Rocks, hanging Woods, the Rivers Severn and Wye, which last winds about the Feet of the Rocks below you, in a very romantic Manner. ... The Rocks ... rise almost perpendicular from the Edge of the Water to a surprising Height, forming, from the great Cliff a Kind of double Amphitheatre. A Gun fired from the Top of this Cliff, creates, by the Reverberation of the Report amongst other rocks, a loud Clap of Thunder, two or three Times repeated, before it dies away: but even this Echo, conformably to the Pride and Grandeur of the Rest of the Place, will not deign to answer a smaller Voice than that of a Musket; with a Culverin, I suppose, it would hold a noble Dialogue. ${ }^{1}$

In characterizing this scene as "sublime" - aligned with the "great", "romantic", "surprising", proud, grand, and "noble" - Dodsley is as much concerned with the sonic properties of space as with the elevated panoramic vantage point which allows him to safely survey the drop to rocks and rivers. Dodsley moves from sights to sounds: Sights locate the spectator and establish the landscape as a waiting stage ("a Kind of double Amphitheatre"); sounds set the space into dynamic movement, action and reaction. This tiny drama of "Reverberation" then takes the measure of nature in relation to human culture, using the fundamental techne of weaponry. Technicians still use guns to test the acoustic properties of buildings, and here sound gives the distanced spectators a literal "Report" on the space's powers. But sound also establishes a more entangled rapport between natural power and human violence, a "Dialogue" which amplifies nature ("creat[ing]" a "loud Clap of Thunder" from a clear day) and affirms human pride.

As Dodsley's letter indicates, the space of the sublime, no less than any other space of enlightenment, was "a practiced place". ${ }^{2}$ This goes for its rhetorical commonplaces, philosophical terrains, and physical environments. Dodsley draws on commonplaces of the sublime partly established by Burke's treatise. He might remember Burke's discussion of the sounds liable to provoke sublime fear: proxies for power, pain and danger like "cataracts", “thunder", "shouting” 
crowds or animals" "cries", but also the "sudden", "repeated", or "intermitting" "stroke" of "clock", "drum" or "cannon" (Dodsley's imagined "Culverin" could itself be a cannon, or a hefty antiquated gun). ${ }^{3}$ Burke's treatise, too, moved from sublime sights to sounds. Sound is treated more briefly, but, as we will see, offers an implicit model for the sublime's underlying processes, one connected with practice and exercise. Dodsley's travels in Wales are themselves part of emerging tourist practices calculated to provoke the sublime, including firing shots into echoic spaces. Physically, too, the eighteenth-century natural sublime relied on land "practiced," shaped or framed by human action. Piercefield was no exception. Inherited by Morris in 1743, it was extensively reshaped and landscaped, and like nearby Tintern became a renowned tourist spot.

At Piercefield, then, Dodsley meets what contemporaries would have called a "second nature," in the sense of cultivated land. Intimately related to space, practice and habit, second nature is the expansive phrase at the center of this article. After sketching its history and counterintuitive relationship with the sublime, I explore points of contact between enlightenment sublimes and one particular philosophy of habit currently attracting renewed attention, that of Félix Ravaisson. My examples focus on overwhelming, indistinct limit sounds, and on a conceptualization of sound as a sublime phenomenon stretching beyond audibility to fill all space, and mark each body's place in relation to others. I close by touching on second nature in a current ecocritical moment for the sublime.

\section{II}

When Michel de Certeau defined space as "practiced place," he was interested in how individuals" everyday uses and habits customized places - physical geographies and architectures - apparently authored and controlled by institutions and systems, and in so doing offered forms of resistance and counter-agency to those larger powers. His ethical vision finds expression in sonic tropes about the limits of the audible. The "ordinary man" to whom de Certeau dedicates his book represents an "impossible object" of research, his "voice ... almost indistinguishable from the rumble of history," a "hero" who "is the murmuring voice of societies" (v). The tropes reappear when de Certeau turns his attention to space. Here, he begins by setting the silent, panoramic perspective on New York city from the top of the World Trade Centre - a masterful perspective of totalizing knowledge and representation - against the "rumble of so many differences", the traffic noises and "chorus of idle footsteps" characterizing lived experience down below $(92,97)$.

De Certeau searches for a science of everyday practice whose only obvious point of contact with the sublime is its resistance to conceptualization and representation, classically aligned with sight. Indeed, the sublime seems a far cry from the everyday, practiced and habitual. True, as 
Dodsley's tour suggests, the sublime is a social practice - cultural not natural, encoding ideologies and hierarchies, associated with practiced poses and dispositions. From a rhetorical perspective, the sublime is structured by commonplaces, tropes, and figures. And from a post-Kantian perspective, everyday circumstances can certainly trigger the sublime, since sublimity names a structure of subjective experience, not (as with Dodsley) a category of objects. Nonetheless, surely the claim of the sublime is to be extraordinary, awe-inspiring, aporetic, epiphanic, non-habitual, natural? Yes and no. This is partly because "nature" has a curious status in habit and in the sublime, both of which have been seen to create a second nature. This capacious phrase can refer to the cultivation of land, the creation of artworks which imitate nature, or the processes of everyday habituation necessary and natural to human nature. In this way, "second nature" approaches "culture," in the sense of the "webs of significance" humans "sp[i]n" for themselves, and within which we live "suspended."

Conceptualizations of "culture" have strong connections with enlightenment and romantic discussion of habit, custom, and by extension prejudice. The classical idea of habit or custom as second nature became commonplace in the Renaissance, and debates around it intensified from the seventeenth century. In "Of Custom," Montaigne paraphrased Pindar fragment 169a to the effect that habit was "Queen and Empress" of all. ${ }^{5}$ (Developing the dark implications of this image in the wake of the French Revolution, Shelley would call "Custom" "the Queen of Slaves / The hoodwinked Angel of the blind and dead". ') Pascal thought custom a "second nature that destroys the former", and suggested that, "as custom is a second nature, so nature itself is only a first custom" - an issue taken up by Hume, and anticipating more contemporary cultural constructivism. ${ }^{7}$ In 1794, the older Burke praised second nature in a way that suggests his reading of Hume and positive revaluation of prejudice: "Man, in his moral nature, becomes, in his progress through life, a creature of prejudice - a creature of opinions - a creature of habits, and of sentiments growing out of them. These form our second nature, as inhabitants of the country and members of the society in which Providence has placed us."

Writing in the same year, from the other side of the political spectrum, William Blake participated in the modern attack on habit in Urizen. This fallen Eternal creates a slimy "Web" or "Net of Religion" which divides Urizen's own children from the sight of eternity, until, their "shrunken eyes clouded over", they "Discernd not the woven hypocrisy / But the streaky slime in their heavens / Brought together by narrowing perceptions / Appeard transparent air", and they "forgot their eternal life". In Urizen, this is what it means to become human, to have "eyes ... like the eyes of a man". Their perceptions "clouded" by the net, and the mesh of the net tightened by their "narrowing perceptions", Urizen's children act out the strange reciprocal creation of 
socialized agents and social institutions - the latter represented as a physical environment coterminous with the skies. ${ }^{9}$ For the poem, both the space of the body and the limited (limiting) space of its external environment are secondary in an emphatically negative sense.

Such negative attitudes towards second nature are familiar today, especially for critics following Kant or Marx. ${ }^{10}$ Habit is a problem, a blockage to change. This dovetails with a dominant contemporary notion of the sublime according to which the habitual is culture, with all its invisible forms, ideologies and conventions. Second nature must be punctured to glimpse what is formless, unmanageable, unconventional, and yet real. In recent theory, a key technology of this puncturing was the sublime, as it appeared in non-representational, formwidrig art. Such art cannot model a utopian space outside culture, but it can shock us out of our habits. Inhabiting this worldview, habit is harder to see as a positive constructive force, and we can miss its role in earlier conceptualizations of the sublime.

Nevertheless, recent years have seen a recuperation of habit, associated especially with the French philosopher Félix Ravaisson (1813-1900). Ravaisson's De l'habitude (1838), recently translated into English, has spawned a rash of studies which repurpose Ravaisson's crusty metaphysics to serve interests in the body, materiality, plasticity, and the transitions between natural and made, sentient life and its others. "Habit is a second nature" is the essay's epigraph. ${ }^{12}$ Drawn from Aristotle's On Memory and Reminiscence, it reflects Ravaisson's more pervasive Aristotelianism, including his fundamental account of habit as key to human nature: It is our nature or disposition to develop and change our dispositions, and so acquire second natures. ${ }^{13}$ For Ravaisson, habit is also key to understanding the rest of nature, the material. Habit supplies a middle term or mediator between freedom and potential on one hand, and mechanical or unfree repetition on the other hand - the kind of thing organisms do to pump blood, or what addicts do when they follow their sensory compulsions in bad habits. ${ }^{14}$

Crucial though not absolute contrasts in Ravaisson's schema are between active and passive, spirit and inorganic matter, and freedom and nature. These pairings are also key to the sublime, particularly in post-Kantian thinking. Friedrich Schiller, for instance, explains that the sublime shows us "that the condition of our spirit does not necessarily conform to the condition of our senses, that the laws of nature are not necessarily also our laws, and that we have an autonomous principle within us which is independent of all sensuous feelings [Rührungen]." "15 The shock of the sublime convinces us of the gap between human nature and nature qua the given and materially determined. In this mode, the eighteenth-century sublime works against or at the expense of nature and embodiment. 
The resonances with Ravaisson are unsurprising, as he drew on Kant as well as Aristotle, and engaged with a similar problematic. For Ravaisson, the pairings of freedom and nature, activity and passivity, relate in turn to what he calls the "double law of habit":

The continuity or the repetition of passion weakens it; the continuity or repetition of action exalts and strengthens it. Prolonged or repeated sensation diminishes gradually and eventually fades away. ... Perception, which is linked to [action and] movement, similarly becomes clearer, swifter and more certain. (14)

Passive sensations are weakened by their own repetition, dulling feeling whether emotional or sensory, while already relatively superior actions are strengthened by repetition. In both respects, however, the resulting habit becomes subconscious, as if involuntary. By extension, no absolute distinction exists between automated addictions and compulsions (typically involving sensory stimulation), and more free or freeing habits - acquisitions and capacities like playing the piano. ${ }^{16}$ For example, certain movements and sensations become automatic for a pianist, allowing her to sight-read, or concentrate on expression rather than technique. This is how piano-playing becomes second nature, returning from effort and conscious change to norm and mechanism. To acquire "perfect execution," as one eighteenth-century manual puts it, our "fingers" need perfect "mechanism." 17 The pianist's muscle memory means aspects of her movement are automated.

Ravaisson's “double law" is key to his philosophical legacy. ${ }^{18}$ Ravaisson asserts that all writers on habit recognize something like it: Habit strengthens perceptions and weakens sensations. But, of course, the very divisions of "perception" and "sensation" are historically contingent and contestable. Ravaisson's schema is broadly consonant with enlightenment-era idealist hierarchies which placed intellect and activity above sensation, matter, and nature (although Ravaisson's ultimate aim is their reconciliation). More specifically, Ravaisson draws on the vitalist Xavier Bichat's Physiological Researches on Life and Death (1799) and Pierre Maine de Biran's Influence of Habit on the Faculty of Thinking (1802). Bichat saw an "inverse ratio" between the dulling of sentiments (feelings) and sharpening of judgements. Both, for him, were cognitive. Feelings involved pre-reflective comparisons between past and present impressions, so that a repeated or continuous sensation necessarily came to seem less novel and extreme (forming a cognitive baseline, we might now say). As pre-reflective comparisons make present sensations less striking, cognitive space opens up for more discriminating judgements. Biran rejected this cognitivism, but likewise discerned an inverse ratio between the intensity of "sensation" (aligned with what he calls passive impressions and pure sensation) and that of "movement" (including active impressions and involving voluntary effort). Biran was working through empiricist, sensualist accounts of the formation of consciousness from passive sensation alone - he steps away from sensualism (with 
its threats to human freedom and agency) by distinguishing voluntary effort as the seed of selfconsciousness and higher activities. Although his reasoning differs, Ravaisson follows Biran's contrast of passive sensation (to which he adds passion) versus action and movement. He uses Leibnizian concepts of spontaneity, force and inertia to posit an equilibrium established by the sense organs when an impression is continuous or repeated.

The signal importance of dulling sensation, for Ravaisson's scheme, thus grows from enlightenment, post-Lockean attempts to explain sensation and its vexed relationship to consciousness and freedom. The emphasis is not apparent in classical discussions of second nature. Hints at precursors, however, are discernable in earlier enlightenment thinking about sound; turning to them suggests intersections between the sublime and habit, alongside moments of friction.

\section{III}

Habit is often imagined through blindness/sight, but deafness/sound also offered compelling tropes to enlightenment-era writers. My examples here relate to a family of sounds at the limits of audibility, too small or too big to grasp, which challenge fully conscious or masterable experience. These sounds approach a vanishing point between the habitual and sublime, invisible white noise and the astonishing noise of a raging waterfall or crowd. They would include rustling, roaring, de Certeau's "murmurings" of society and "rumble" of history, even the movements of the spheres.

Limit sounds are philosophically freighted in ways that resonate with Ravaisson. For G. W. Leibniz, they helped to imagine the fact that humans possess "an infinity of perceptions" of which we are unaware because they are "too minute", "too numerous" or "too unvarying." These little perceptions are like the sounds of the "roaring" "sea," which we must hear even though we cannot consciously perceive "each wave": Without "confused" unconscious perception of each "little noise", "there would be no perception of a hundred thousand waves, since a hundred thousand nothings cannot make something". Leibniz also notes that those living next to a "mill or waterfall" forget its noise; yet the mill is still theoretically audible, given proper attentiveness. ${ }^{19}$ These passages form part of Leibniz's defense of his rationalist philosophy against Lockean empiricism, where humans are not open to the infinite, but receive only limited, potentially distorted, data about the world through finite sense perceptions.

Before Leibniz, the influential theorist Marin Mersenne had explicitly linked limit sounds with second nature in his Traité de l'harmonie universelle (Treatise on Universal Harmony, 1627). He also explicitly formulates what seems to be an early connection between second nature and loss of sensation. Treating metaphysics alongside acoustics and physics, Mersenne touches on the classical 
question of why we cannot perceive cosmic music, despite being profoundly influenced by it. This must be because cosmic music is

too large, like those [sounds] of the cataracts of the Nile which deafen the inhabitants of Catadupa, if the ancients do not deceive us; or because the concert of the heavens is so ravishing that it lulls to sleep and charms our ears; or we are accustomed to that music from our mothers' wombs, and custom is a second nature that robs us of sensation - just as happens to those who live near coppersmiths, blacksmiths, and armorers, for after some years they almost no longer hear the noise which at first troubled them. ${ }^{20}$

The deafened villagers of Catadupa derive from Cicero's Dream of Scipio in Republic 6.19, preserved in Boethius' De musica, the key source for early modern images of cosmic music. The commonplace about habit is not found in the Dream of Scipio (although Boethius was influenced by neo-Platonic concepts of second nature and sound). ${ }^{21}$ It instead recalls Aristotle's On the Heavens. In rejecting the existence of cosmic music, Aristotle cites the Pythagorean idea that we cannot hear the music of the spheres because "the sound is with us right from birth and has thus no contrasting silence to show it up; ... and so all mankind is undergoing an experience like that of a coppersmith, who becomes by long habit indifferent to the din around him." This, Aristotle replies briefly, "cannot be true" (2.9.290b). ${ }^{22}$ But Mersenne arguably thinks of Cicero again when he calls custom a second nature. Cicero had used the phrase twice. In De natura deorum 2.60, he praises the cultivation of nature through agriculture: "we seek with our human hands to create a sort of second nature [alteram naturam] in the natural world." More pertinent to questions of human cultivation, De finibus 5.74 explains that "habit produces a sort of second nature [altera natura], which supplies a motive for many actions not aiming at pleasure at all." In other words, at first, pleasure is the object of desire, but later habit takes over and motivates actions without fresh stimulus to direct the will.

Neither Ciceronian text, however, associates second nature with loss of sensation in the way that Mersenne and Ravaisson do. Nor does Aristotle. Aristotle's On Memory mentions second nature in explaining how we come to "naturally" recall things from long ago, by dint of remembering them frequently. ${ }^{23} \mathrm{~A}$ pseudo-Aristotelean text associated with the phrase in the Middle Ages and Renaissance, the Problemata, brings up habit in a discussion of sexual preferences, asking why some men come to prefer anal sex as if it were "natural". The passage is grammatically difficult, but seems to propose that submitting to pederasty sometimes becomes habitual: teenage boys "therefore desire to do the act by which pleasure and the emission of semen are produced, and habit becomes more and more a second nature." 24 The idea of habit dulling sensation is again absent: habit excites. 
This leads us back to the sublime, another intense positive experience classically beginning when a subject is passive - overwhelmed by what John Dennis called a "pleasing rape." 25 Within this discourse, noise is often positioned as new or astonishing and as retaining sensuous impact over time, and indistinct rushing and rustling sounds can be coded as sublime, contributing to more fully embodied, situated sublimes than those of Schiller or Kant. ${ }^{26}$ The sublime, then, threatens to undermine the distinction between often negative, weakening, bodily/sensorial passivity and positive, strengthening, mental activity. As early as Longinus's oratorical sublime, listeners gain power and elevation by feeling they have spoken what they have only heard (Longinus 7.2). They submit to a delusion about agency as well as submitting to a speaker's irresistible power. We also learn to create sublime effects for others by submitting to the models of past masters. The sublime, then, shares habit's keynotes of repetition and practice. Through Longinus's manual or technologia, we go through the motions of experiencing sublime discourse, and learn techniques to "sublime" our own speeches. We traditionally imagine nature triumphing over art and rules in the sublime, yet Longinus affirms that "art is perfect when it appears like nature, nature ... successful when it embraces concealed art" (22.1). James Porter's recent study shows just how much Longinus affirms techne (art) as the improver of nature and a guide to making natural-seeming art: “to the extent that Longinus's project aims to instruct aspiring writers in how to make their own natures sublime, his work constitutes nothing less than a technology of nature". ${ }^{27}$ Indeed, Porter discerns the workings of second nature in Longinus's treatise, which "exploit[s]" the traditionally blurry division between nature and art as it applies to the apparently natural conventions of rhetoric, the "second nature" of representative art, or to humans" "moral or ethical nature", shaped by “education, taste, [and] habit" (72, 77, 83; compare Longinus 22.1, 32.6).

The importance of habit and second nature were not lost on eighteenth-century theorists of the sublime, despite their emphasis on terrifying nature. For Burke, for instance, the sublime force of raging cataracts, roaring crowds, and repeated cannon shots (or even the poetry of Milton) are not said to lessen with repeated encounters. In his own use of second nature, Burke moreover brings the sublime closer to the habitual than might be expected. It is true that absolutely "constant use" or "custom" causes indifference, he writes: "Very justly is use called a second nature; and our natural and common state is one of absolute indifference, equally prepared for pain or pleasure" (III.5.189-90; compare I.1.41-3). The customary is therefore distant from the "extremely rare and uncommon" positive pleasure of beauty (III.5.187). Yet sublimity, by contrast, is neither positively pleasurable, nor exactly painful. It lies between pain and indifference, in what Burke calls "tranquillity shadowed with horror," when we still remember and feel the physiological reverberations of terror but are returning to a more habitual state (I.3.49). 
The physiological dimension of the sublime is key for Burke. Practicing the sublime strengthens our vibrating nerves, which are otherwise liable to convulsions and pathology when faced by shock (IV.7.256). ${ }^{28}$ In its recourse to nerve theory, the treatise allows sound to furnish an implicit model for the sublime's underlying physiological processes, insofar as sound's repeated striking of the air mirrors the "vibrat[ion]" of the "ear-drum" in hearing, and such vibrations mirror our invisible shaking nerves (IV.11.265-6). These comments belong to a chapter on "The artificial Infinite" which continues an earlier discussion of infinity. There, Burke conceded that "there are scarce any things which can become the objects of our sense that are really ... infinite", yet argued that the "effects" of infinity were created for our limited senses by "indefinite" repetitions (I.8.129-30). Even after these indefinite stimuli cease, the senses continue the impulses by vibrating long after. An illustration tellingly reverses the logic of noise seen earlier: "After a long succession of noises, as the fall of waters, or the beating of forge-hammers, the hammers beat and the waters roar in the imagination long after the first sounds have ceased to affect it; and they die away at last by gradations which are scarcely perceptible. ... The senses, strongly affected in some one manner, cannot quickly change their tenor, or adapt themselves ... but they continue in their old channel" (I.8.130-31). For Mersenne and Leibniz, repetition dulled sensation, leading to acquired insensibility to cosmic harmony or infinite tiny waves. For the Lockean empiricist, Burke, sensation is extended and intensified in a sublime illusion or impression of an infinity never genuinely accessible. This "mechanism" of sensory repetition (a form of inertia) can even become dangerous, leading "madmen" to spend "days", "years" or whole "lives" "in the constant repetition of some remark, some complaint, or song" which once "struck [them] powerfully" (I.8.131). In other words, sublimity blends into pathological bad habits.

More broadly, for eighteenth-century writers the fact that the sublime was repeatable separated it from novelty or the foolish astonishment of the ignorant. ${ }^{29}$ Novelty wears off. Sublime art keeps its value and even works more intensely the better we know it (compare Longinus 7.3). This makes sublimity apparently reconcilable with connoisseurship in discourses on habit, a category which exemplified the distinction between sharpened perceptions in good habits or skilled practices (the wine-lover) and dulled sensations in addiction (the drunkard) (Ravaisson, 49). Yet the sublime would stop being sublime if it became a matter of practiced connoisseurship, of experiences "owned" or "mastered" from the outset by a self-possessed subject. Leaving aside the problem of alcoholic wine-buffs, a more neutral example of skilled practice sees a person first overwhelmed by the scent of beautiful flowers in a meadow, then growing to distinguish each scent (Carlisle, 29, discussing Bichat). Such improving powers of sensory distinction fall outside most understandings of the sublime. Even for someone like Schiller, for whom the sublime 
plausibly sharpens active perception rather than sensation, and reveals an autonomous spirit free from sensations, the sublime must feel overwhelming. No matter how many times we experience it, it must register as a shock to the senses and our natural-mechanical capacities. It thus has at least the flavor of taking us beyond the subject, of ex-stasis.

Schiller does not use the phrase second nature in his essays on the sublime. But he brings to a point a key way that this aesthetic creates a second nature, one adumbrated by Longinus: The experiences of adversity and terror which trigger the sublime create a second buman nature, by developing capacities otherwise swamped by our first nature as comfy sensuous beings in a world of beautiful appearances. In Schiller's words, human nature is only an "accidental form of existence" until we are completed by "aesthetic education" in the sublime and beautiful. This remakes us as "complete citizens of nature, without being her slave" (840). Aesthetic education involves practicing resistance to nature, in art. In this sense, art, too, forms a second nature - an arena where we practice the moral disposition necessary to "complete citizens of nature." Longinus had already presented a literal contrast between semi-conscious slavery and full political participation as the ultimate justification for a sublime rhetorical re-education: Readers need to be jolted out of the customs of decadent, undemocratic, mercenary Roman society. Thus a "certain philosopher" observes towards the text's end that "today ... we seem in our boyhood to learn the lessons of a righteous servitude, being all but enswathed in its customs and observances, when our thoughts are yet young and tender, and never tasting the fairest and most productive source of eloquence (... I mean freedom), so that we emerge in no other guise than that of sublime flatterers" (44.13).

The sublime as an educative process which created a second human nature was crucial for the critic and philosopher Johann Gottfried Herder (1744-1803). Herder offers thoroughly sonic models of the sublime which explicitly involve repetition. According to his late anti-Kantian aesthetic treatise Kalligone, the "raw-sublime dreams of our childhood" give way in adulthood to a spiritual but also sensuous glimpse of what is "simultaneously the most beautiful and the highest", that is, the true sublime, which Herder sees as the height rather than the antithesis of beauty. ${ }^{30} \mathrm{He}$ repeats the narrative of sublime development in the same passage, in an anecdote about the sounds of a sea storm, first heard as terrifying, but ultimately perceived as full of rhythmic "pulse" and "harmony", with the manmade ship moving "in unison" with the "elements", and the world responding freely in "sublime ... order" to a single aural "call" (3:24-5). Similarly, in his essay Cecilia, humans' natural impulse to sing develops from a dark, raw, privative, confused sublime the kind Burke had made popular - into a truly sublime hymnody which recognizes a beneficent, orderly nature. In a state of nature, humans are "surrounded by the monstrous power and 
superiority of creation", and cry out the hymn: "monstrous power, do not crush me! help me?' But they increasingly find in nature "rules of wisdom," "benignity and mildness"; an "order" that "serves" us, and that we "must serve". We naturally - second naturally - move to praise the creator of those laws and that nature, and in singing are "raise[d]" up to the "highest ideal of creation, to God". ${ }^{31}$ From his earlier essay on the origins of language, it is clear that human development is not simply a matter of long-term stadial development, nor of infant development, but of developing our analytical understanding of what origins are like through different speculative analogies: Our first tendency, in his analysis, is to see brute physical forces and attendant painful sensations at the origins of all things; on second thoughts, we see a second element in our nature driving the emergence of language, the element of reflection (Besonnenheit). ${ }^{32}$

Herder and Schiller suggest that the sublime is not only repetition-resistant, but predicated on repetition and habituation. Herder's emphasis on change particularly chimes with a formulation from Ravaisson: Habit involves a "change, with respect to the very change that gave birth to it", so that, "if change is [by definition] transitory, habit subsists beyond the change which brought it about" (25). Here, we have "change [in the encounter with sublimity], with respect to the very change that gave birth to it", that is, the encounter with sublimity, which strikes us as a change from the ordinary, containable course of things. Herder's sublime, like habit, is iterative.

Herder as much as Schiller could be said to privilege "active" perception and reflection over sensation. Nonetheless, Kalligone's aesthetics goes beyond perception, action and control. Returning to my earlier image, the true sublime seems less like mastering the piano than like learning to imagine the universe as "an odeum, a hall of eternal harmonies," where every object is a corps sonore or "sounding body", striking other bodies and so "ringing" out, forming "consonances" "to an unreachable height and depth," "to an imperceptible, untraceable degree" $(1: 106,108)$. Rather than striking keys, subjects are themselves struck; they reconceive themselves as implicated in a system exceeding their reach and perception.

Herder also illustrates the sonic sublime's close relationship with repetition per se in the long eighteenth century. This went beyond the idea of patterned sounds created by composers and perceived by connoisseurs. As is suggested by Herder's vocabulary of "sounding bodies" - taken from contemporary acoustic theory - sound and repetition were linked by the material and acoustic "nature" of sound: Bodies vibrating to and fro repeatedly struck the air, and communicated shocks to the ear drum and nerves. For Herder, implicitly, this made sound almost constitutively sublime. While light in Kalligone is "softly-charming," sound is "shattering, stirring"; it is "the voice of all moving bodies," "their suffering, their resistance, their aroused powers announcing themselves" (1:101-2). 
The dynamic between passive "suffering" and active "resistance" in Herder's phrase suggests once more the possible limits of dividing the beginnings of habit into (higher) active perception and (lower) passive sensation, as Ravaisson did. This hierarchical division is of course unfashionable today. Now, amid critiques of human pretensions to mastery or to supersensuous, non-situated knowledge, the sublime is nonetheless making a small ecocritical comeback which again links sublimity with second nature, albeit in an altered sense. Second nature now describes less human nature, society, or art, than a physical environment which - like a cataract or thundering storm threatens us with destructive power, but which is "second natural" in being indelibly shaped by capital, industry, technology or other human interventions. ${ }^{33}$ In the Anthropocene, we might say, all natural threats look second natural.

One brief illustration comes from Damien Hirst, whose well-known installations-cumsculptures have been suggestively interpreted alongside the sublime by Luke White. A good example is The Physical Impossibility of Death in the Mind of Someone Living (1991) - an immense white steel vitrine housing a shark preserved in formaldehyde - linked by White with eighteenthcentury depictions of sharks as natural threat par excellence. ${ }^{34}$ Suspended in the blue-tinted medium, Hirst's shark seems to be swimming, jaws and eyes wide open, towards something it will never reach, bringing viewers to the double aporia of the shark's death and their own. Both these deaths are real (in different ways), and both imaginatively implausible, thanks to the second nature of the artwork, and to death's resistance to thought, part of the second nature of mental conventions and illusions which sustains our everyday habits. Refraction means that the shark can seem to be swimming at us twice, through different faces of the vitrine, and so seems "non-identical" with itself - a characteristic Adorno linked with the sublime, although, as White notes, Adorno thought this aesthetic had come to the end of its natural life by the 1960s. White links Hirst's work with the late-capitalist, media-saturated repurposing of the shark as a symbol of human predatoriness. But in a world whose oceans are now suffused with invisible microplastics, it is increasingly easy to read the formaldehyde-saturated shark as "second natural" in a more literal and environmentalist sense. Another piece from the same year, The Acquired Inability to Escape (1991), suggests Hirst's interests in second nature in the related senses of habit, addiction, and enculturation. The work comprises a black steel vitrine suggestive of prison bars, holding a functionalist office chair and desk, a cigarette and full ashtray. The psycho-physiological "inability" of the smoker to escape her habit neatly rhymes with the inability of the worker to escape an office job - metonymically represented by the space of the office - which nothing but social and cultural conditioning (and a big steel vitrine) would make it impossible to leave. 
The artificial, invisible, yet ever-present limits of Urizen, The Truman Show, or Hirst's shark cage all function as critiques of second nature, and all trope culture as physical space. In the last lines of Urizen, desolate yet hopeful, the "remaining children of Urizen" see "their brethren shrink together / Beneath the Net of Urizen." Unable to reach and awaken their "wither'd, \& deafen'd" "ears" - lacking the sublime oratory Longinus hoped could pierce Roman habits of slavery - the chosen few "left the pendulous earth: / They called it Egypt, \& left it. / And the salt ocean rolled englob'd" (Plate 28, ch. 9, 11. 20, 12-13, 15-16, 18, 21-23). We do not have the option of leaving our "earth", neither the second nature of the Anthropocene nor our acquired human natures. If Ravaisson offers any hope in the contemporary moment, it is perhaps the reminder that habits are not only permanent residues of changes wrought in and by humans, but that "habit remains for a change which either is no longer or is not yet; it remains for a possible change" (25). ${ }^{35}$ The practice of the sublime, if we have any taste for it today, might be a prompt for such change, but not plausibly because it simply escapes habit and culture.

Notwithstanding the persistence of the sublime, critics now not infrequently recoil from it as an aesthetic which harvests one man's pleasure from others' pain and exploitation - be that the enjoyment of a shipwreck (Lucretius), the appreciation of a stylish murder (De Quincey), or the more insidious conversion of nature into a spectacle exploited by a distanced, masterful subject. Dodsley's impressions of Piercefield in 1759, with which this article began, open another perspective on the ethical terrors of the sublime. The estate of Piercefield had been bought in 1743 by Valentine Morris's father, with a fortune made in Caribbean sugar plantations. A few decades later, an impoverished Morris was forced to sell the property and move to the Carribean himself. On St Vincent, wrote another visitor to Piercefield, William Coxe, Morris “distinguished himself with so much zeal and activity in promoting the cultivation of the island, where he almost raised another Piercefield, that he was soon after nominated governor. ... he considerably improved his fortune, and had almost repaired his losses, when the island, for the defence of which he advanced considerable sums, was taken by the French." 36 Writing in the midst of the Revolutionary wars, Coxe saw a different sting in the twists and turns of Morris's fortune than that which we likely see today. The staging of sublime nature at Piercefield relied not only on the concealed work of landscaping, but on the distant labor of Caribbean slaves. The second nature of this Welsh estate was emulated in a second second nature at St Vincent, made "almost ... another Piercefield" tacitly through more slave labor.

This is perhaps familiar territory in critiques of eighteenth-century aesthetics: allegedly natural scenes are cultivated; familiar sublime scenes rely on networks of distant and unfamiliar places; disinterested aesthetics relies on interested economies and denaturalizing exploitation of 
people and land. But attention to sound here may suggest slightly different directions. Dodsley's impression of the natural "Amphitheatre" at Piercefield, where gun-shot holds a dialogue with its reverberations from the rocks, has interesting resonances with Herder's impressions of sound. For Kalligone, the everyday workings of sound revealed the universe as an "odeum" - another classical space for musical performances - connecting all bodies with each other in infinitely complex relationships and reverberations. Herder is certainly no ethical paragon, but his writing, alongside others' touched on here, suggests the continuing affordances of eighteenth-century aesthetics. The vibrations and resonances fundamental to sound can construct a sublime that is irreducibly relational, setting the auditor in a participatory network of bodies and spaces. The practice of listening here becomes a techne of the sublime - an art which strives to look like an encounter with nature, and which aims to remake our natures.

This article took shape at "Habits and Spirits" (King's College London, 2016), convened by Zeynep Bulut and Brendan Jamal Thornton, and "Natures and Spaces of Enlightenment," convened by Peter Denney and Lisa O'Connell. My thanks to conveners and participants, especially Matthew Head, Martin Stokes, and Clare Carlisle, alongside Gaye Mitchell, Michael Champion and Matthew Champion.

${ }^{1}$ Robert Dodsley to William Shenstone (12 October 1759), in The Correspondence of Robert Dodsley, 1733-1764, ed. James Tierney (Cambridge: Cambridge Univ., 2004), 424. 
${ }^{2}$ Michel de Certeau, The Practice of Everyday Life, trans. Steven Rendall (Berkeley: Univ. of California, 1984), 117.

${ }^{3}$ Edmund Burke, A Philosophical Enquiry into the Origin of Our Ideas of the Sublime and Beautiful, 2nd ed. (London: R. \& J. Dodsley, 1759), Part II, sections 17-20, 150-56.

${ }^{4}$ Clifford Geertz, The Interpretation of Cultures (New York: Basic Books, 1973), 5.

${ }^{5}$ The Essays of Michael de Montaigne, $9^{\text {th }}$ ed., 3 vols. (London: W. Miller, et al., 1811), 1:119. See Margaret Watkins, "Negotiating with a New Sovereign: Montaigne's Transformation of Habit into Custom”, in A History of Habit: From Aristotle to Bourdieu, ed. Tom Sparrow and Adam Hutchinson (Lexington, Mass.: Lexington, 2013), 89-118.

${ }^{6}$ Percy Bysshe Shelley, Laon and Cythna, 11. 1622-4, discussed in Ross Wilson, Shelley and the Apprehension of Life (Cambridge: Cambridge Univ., 2013), 62-63.

${ }^{7}$ Donald Kelley, "'Second Nature': The Idea of Custom," in The Transmission of Culture in Early Modern Europe, ed. Anthony Grafton and Ann Blair (Philadelphia: Univ. of Pennsylvania, 1990), 160-61.

${ }^{8}$ Edmund Burke, "Seventh Day" in the impeachment of Warren Hastings, quoted in James Chandler, Wordsworth's Second Nature: A Study of the Poetry and Politics (Chicago: Univ. of Chicago, 1984), 71. Compare Valentin D’Agnano, “De l'Angleterre à la France: Métaphysiques des mœurs chez Burke," in Entre nature et histoire - Mours et coutumes dans la philosophie moderne, ed. Francesco Toto, Laetitia Simonetta, and Giorgio Bottini (Paris: Garnier, 2017), 273-290. ${ }^{9}$ William Blake, The [First] Book of Urizen, in The Complete Poetry and Prose of William Blake, ed. David Erdman, rev. ed. (New York: Doubleday, 1988), Plate 25, ch. 7, 11. 5, 9-13, 20, 22, ch. 9, 11. $13-14,9,12$.

${ }^{10}$ See Norbert Rath, Zweite Natur: Konzepte einer Vermittlung von Natur und Kultur in Anthropologie und Ästhetik um 1800 (Münster: Waxmann, 1996); Christoph Menke, "Zweite Natur. Kritik und Affirmation,” in „...wenn die Stunde es zulässt“. Zur Traditionalität und Aktualität kritischer Theorie, ed. Malte Völk, et al. (Münster: Westfälisches Dampfboot, 2012), 154-71; Maik Puzic, Spiritus sive Consuetudo. Überlegungen zu einer Theorie der zweiten Natur bei Hegel (Wurzburg: Königshausen \& Neumann, 2017).

${ }^{11}$ See Elizabeth Grosz's survey, "Habit Today: Ravaisson, Bergson, Deleuze and Us," Body $\mathcal{E}$ Society 19 (2013): 217-39; Clare Carlisle, On Habit (Abingdon: Routledge, 2014).

${ }^{12}$ Félix Ravaisson, Of Habit, ed. and trans. Clare Carlisle and Mark Sinclair, preface by Catherine Malibou (London: Continuum, 2008), 25. 
${ }^{13}$ See Aristotle, Eudemian Ethics 2.2, further Rhetoric 1.11.1; Ravaisson, Of Habit, 119n1.

${ }^{14}$ Compare Hegel's Philosophy of Mind, $\$ 410$, which see habit as mediating between nature and freedom. Carlisle, On Habit, 16.

${ }^{15}$ Friedrich Schiller, "Über das Erhabene" [1801?], in Theoretische Schriften, ed. Rolf-Peter Janz, et al., vol. 8 of Werke und Briefe in zwölf Bänden (Frankfurt a.M.: Deutscher Klassiker Verlag, 1992), $822-40$.

${ }^{16}$ Compare Carlisle, On Habit, 105.

${ }^{17}$ Jean Philippe Rameau, Pieces de clavessin avec une method pour la mechanique des doigts, où l'on enseinge les moyens de se procurer une parfait execution... (Paris: Charles-Etienne Hocherau, et al., 1724).

${ }^{18}$ This paragraph follows the 'Editors' Introduction', Of Habit, 8-15.

${ }^{19}$ Gottfried Wilhelm Leibniz, New Essays on Human Understanding, trans. Peter Remnant and Jonathan Bennett (Cambridge: Cambridge Univ., 1996), 53-54. Compare Miranda Stanyon, "Sublime Rauschen: Enlightening Sound from Locke to Klopstock," Modern Philology 111 (2017): 861-62.

${ }^{20}$ Marin Mersenne, Traité de l'harmonie universelle (Paris: Guillaume Baudry, 1627), 71. Compare Stanyon, $862 \mathrm{n} 73$.

${ }^{21}$ See Stephen Blackwood, The Consolation of Boethius as Poetic Liturgy (Oxford: Oxford Univ.,

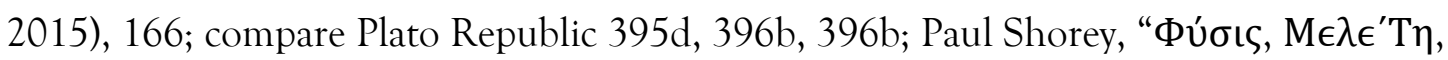

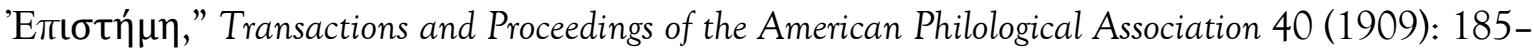
201.

${ }^{22}$ Aristotle, On the Heavens, trans. W.K.C. Guthrie (Cambridge, MA: Harvard Univ., 1939), 193-4.

${ }^{23}$ Interestingly, recent translations avoid the phrase second nature. Aristotle on Memory, trans. Richard Sorabji (Chicago: Univ. of Chicago, 1972); Aristotle on Memory and Recollection, ed. David Bloch (Leiden: Brill, 2007).

${ }^{24}$ Problemata, trans. E. S. Forster, vol. 7 of The Works of Aristotle, ed. W. D. Ross (Oxford: Clarendon, 1972), 4.26, 879a-880a. For medieval and early modern reception, see Faith Wallis, “Giulio Guastavini’s Commentary on Pseudo-Aristotle's Account of Male Same-Sex Coitus, Problemata 4.26," in The Sciences of Homosexuality in Early Modern Europe, ed. Kenneth Borris and George Rousseau (London: Routledge, 2008), 57-74.

${ }^{25}$ John Dennis, The Grounds of Criticism in Poetry (London: Strahan, 1704), 79.

${ }^{26}$ Stanyon, "Sublime Rauschen," 855-57. 
${ }^{27}$ James Porter, The Sublime in Antiquity (Cambridge: Cambridge Univ., 2016), 70.

${ }^{28}$ Compare Aris Sarafiano, "Pain, Labor, and the Sublime: Medical Gymnastics and Burke's Aesthetics," Representations 91 (2005): 58-83.

${ }^{29}$ See, for example, Johann Jacob Breitinger, Critische Dichtkunst, 2 vols. (Zurich: Orell, 1740), 1:24; compare Longinus 7.2-4.

${ }^{30}$ Johann Gottfried Herder, Kalligone, 3 vols. (Leipzig: Hartknoch, 1800), 3:21.

${ }^{31}$ Johann Gottfried Herder, Cäcilie, in Zerstreute Blätter. Fünfte Sammlung (Gotha: Carl Wilhelm Ettinger, 1793), 297.

${ }^{32}$ Johann Gottfried Herder, Abhandlung über den Ursprung der Sprache, in Frühe Schriften, ed. Ulrich Gaier, vol. 1 of Werke in zehn Bänden (Frankfurt a.M.: Deutscher Klassiker Verlag, 1985), 716-22.

${ }^{33}$ See, for instance, Helena Feder, Ecocriticism and the Idea of Culture: Biology and the Bildungsroman (Farnham: Ashgate, 2014), 71; Angus Carlyle, "Becoming Second Nature: Dan Holdsworth and the Sublime", in Dan Holdsworth (Photoworks/Steidl: Göttingen, 2005), 38-45; Luke White, “Damien Hirst's Shark: Nature, Capitalism and the Sublime”, Tate Papers 14 (2010), <http://www.tate.org.uk/research/publications/tate-papers/14/damien-hirst-shark-naturecapitalism-and-the-sublime>.

${ }^{34}$ White, "Damien Hirst's Shark". Images at Damien Hirst, $\langle\underline{\text { http://www.damienhirst.com/the-physical-impossibility-of }>}$.

${ }^{35}$ Compare Malibou's preface, viii.

${ }^{36}$ William Coxe, An Historical Tour in Monmouthshire, 2 vols. (London: T. Dadell, Jr and W. Davies, 1801), 2:393-94. 


\section{University Library}

\section{- M M I N E R VA A gateway to Melbourne's research publications}

Minerva Access is the Institutional Repository of The University of Melbourne

Author/s:

Stanyon, M

Title:

Second Nature and the Sonic Sublime

Date:

2021-09-01

Citation:

Stanyon, M. (2021). Second Nature and the Sonic Sublime. Eighteenth-Century Life, 45 (3), pp.178-196. https://doi.org/10.1215/00982601-9273041.

Persistent Link:

http://hdl.handle.net/11343/285050 